\title{
Family Education Model in Early Childhood Character Building Values for Poor Urban Fishermen Family in Semarang City
}

\author{
Emmy Budiartatia ${ }^{\mathrm{a}}$, Mintarsih Arbarini ${ }^{\mathrm{b}}$, Utsman $^{\mathrm{c}}$
}

\begin{abstract}
Traditional fishing lives in limitations environment, it causing them had to get along with imprisonment poverty. As a result, they pay less attention to the family education. Their children grow up with deficient character. To anticipate and to cope with these circumstances requires a family education model to form their character building to prevent children's destructive behavior from an early age to this society. The purpose of the first stage (1) / year study resulted in a socioeconomic description in relation to family education needs. It then produced a conceptual model of family education designed in a family education draft that embodies the values of exemplary character and virtues rooted to religion, culture, citizenship and manners that are easily understood and well applied to the fishermen's families. The research is carried out in three (3) stages / year. The procedures include: 1) Identification of the socio-economic condition of the family, 2) the pattern of family education, 3) the parent's role to form early childhood character building and 4) the family's educational needs to form early childhood character building to obtain good personality. The results showed 1) that poor families in the fishing village have undergone many changes in terms of social economy. This happens because of government intervention that has provided adequate facilities for fishermen, such as soft loans to own a boat. 2) The pattern of family education and the role of parent's changes. 3) A better life makes parents pay more attention to their child's education in general and character education in particular. 4) Viewed from the parent's educational background which is generally low, it requires a guidance to provide the parents needs to understand and apply the character education of the early childhood character appropriately. The guidance contains the information about the character building regards to some values of emotional, social and intellectual adjusted to the parent's ability and family patterns.
\end{abstract}

Keywords:

\section{INTRODUCTION}

Poverty of fishermen in urban areas is something unique and very complex, because there are several factors that affect the creation of family poverty itself. Some aspects of poverty in urban families include: personal aspects, family, group, community, and government policy also become a variable affecting the poverty of urban families (Sjafari, 2014: 15).

The pattern of life of poor families in urban areas is faced with a very hard and distinctive life pressure. This is due to the quality of life of poor families is twisted by problems of economic limitations, backwardness of education, and difficulties in accessing various public services.

Sjafari's research results (2014: 107) revealed that urban poor families do not have enough education to develop patterns and methods that are able to internalize positive values for family members.

Such conditions lead to a family culture tied with character values in the end unable to cultivate and strengthen motivation in life. In general, the planting of character values in poor families in urban areas uses advice and punishment to carry out the process of socializing values within the family. For that, it takes a family education model that is easier to apply the values of better characters.

In the family, parents will meet all the needs of the child in the form of physical needs include; Food, clothing, shelter, and other necessities. Nonphysical needs include; Affection, attention, caress, praise, reproof, and habits that can develop the potential of the child from birth.

Parents of poor fishermen who are busy working at sea to improve the family economy, sometimes have little spare time interacting with children indicating that the family has lost much of its essential role and loyalty to the child. For that loyalty has led to other educational institutions that force the family to work with it, even surrendering responsibilities to the school.

Based on the results of previous research (Budiartati, 2013) that the urban poor fishermen families of Semarang very minimal attention of parents to the education of their children, especially on the development of values. According to the parents' view of the fisherman, the education of the child has simply been left to the school or teacher only. As a result, early childhood fishermen become 
abandoned in the formation of character that should be obtained from his family.

Early age is a golden age (golden age) in which the physical, cognitive, language, and social development took place very rapidly. This period is a sensitive period to receive stimuli (stimuli) and is crucial for child development in the future (Jamaris, 2008). If at this time the potential of the child is not developed as optimal as possible, then the child will experience a big loss, because this period will never happen again. Therefore, it becomes the duty of parents to help the potential of children can develop optimally.

A preliminary survey of fishing families found information that parents instilled early childhood character values based on intuition and passed down through generations, character-planting activities without the knowledge being learned from books on the cultivation of children's character values early age. In the preliminary study can be identified almost all parents in the family of fishermen background of elementary school, and junior high school, so the ability to educate and instill the values of the characters in their early child performed according to ability.

Based on the description of the background, it is very necessary efforts to plant the values of the characters in early childhood poor urban fishermen families in order to develop the character as early as possible. The model of family education used in this study is the family education model in planting the values of early childhood characters aged between 4-6 years (age of kindergarten) for poor urban fishermen families so that early childhood will be protected from destructive behavior and Deviate. Furthermore, through family education is instilled values of virtue and exemplary by their own parents.

Based on the formulation of the above problem, the purpose of this study as follows:

1. Describe the socio-economic condition of the urban poor fishermen families of Semarang.

2. Describe the pattern of education of poor urban fishermen families in the planting of character values in early childhood.

3. Describe the role of parents of poor urban fishing families in the planting of character values in early childhood.

4. Describe the educational needs of urban poor fishermen families to the values of early childhood character in the formation of good personality in the city of Semarang.
5. Develop a model of family education in planting the values of early childhood character in poor urban fisherman families in Semarang City.

6. Knowing the effectiveness of family education model in planting the values of early childhood character in poor urban fisherman family in Semarang City.

\section{RESULT AND DISCUSSION}

\subsection{Research Approach}

This research uses research and development approach from Gall, Gall, \& Borg (2007). This type of research and development is based on the consideration that the research and development is intended to produce a model product that is procedural. This study aims to develop a family education model in planting early childhood character values for poor urban fishing families, so it is appropriate to use models from Gall, Gall \& Borg (2007). For the needs of research and development is tailored to the purpose and actual research conditions that occur in poor urban fishing families who have children early in the city of Semarang.

\subsection{Research procedure}

This research and development procedure uses a simplified research and development model from Gall, Gall \& Borg (2007) in 3 stages: 1) preliminary study; 2) model development; And 3) product testing. In the preliminary study phase the steps are:

A). Conduct literature studies that are used to collect support materials. Supporting materials needed in research and development include family education, character values for early childhood, and poor urban fishing families.

B). Conduct field studies that include: (1) the social and economic conditions of poor urban fishing families, (2) the educational pattern of urban poor fisherman families, and (3) the character values implanted in their children.

C). Describe the pattern of education of urban poor fishermen families that have been applied and analyze the problems of family education in the inculcation of character values in early childhood. 
This research is important in terms of generally low parental education background, parents need guidance so that they can understand and apply the proper inculcation of character values for early childhood. The guidance is information about the cultivation of the values of character in the family include the value of emotional, social and intellectual characters tailored to the ability of parents and family care patterns.

The subject of this research is poor urban fisherman families who have early childhood between 4-6 years old in fisherman's village of lorok pond of Tanjung Mas village, North Semarang district. The number of research subjects was 70 families of fishermen.

\subsection{Research Results and Discussion}

The results of research in the first stage is the early stage of the development of family education model in the planting of early childhood character values that are easily understood and applied by the poor urban fishermen. This initial phase of activity successfully identifies the socio-economic conditions of urban poor fishermen in planting the values of early childhood character, the role of parents of poor urban fishing families in planting the values of early childhood character, and the educational needs of urban poor fisherman families in the planting of values Character on the formation of a good personality in the city of Semarang. The results of complete identification are described as follows:

The Socio-Economic Condition of the Urban Poor Fishermen Family

Identification and data were collected through interviews with families of fishermen who had early childhood in the planting of character values, documentation study was conducted by meeting the chairman of RW and RT to know the families of fishermen who have early childhood. The results of the documentation study show that the fishing area consists of RW 5, ie RW 12, 13,14, 15, and 16. Each RW consists of several RTs.

The results of interviews with fishermen's families, indicating that the fishermen work (sea) is not every day because it adjusts to the state of nature. Some go to sea in the morning and some work at night. If their catch is only about 2 to 4 hours. The catch is not enough to meet the needs of the family, so it must be indebted, which will be paid at the time of harvest. But during the good season (the harvest season) in February, March, and April, they can spend between 6 to 8 hours to sea and get results that can be used to pay debts at the time of the catch is empty.

Some fishermen families not only rely on the catch of fish from their husbands. Wives help supplement family income by working in factories. Such families can generally improve their standard of living for the better. The tasks of the fishermen's wives who do not work outside in addition to their main tasks in the domestic sector (household affairs) are to sort out the catch from the sea in the form of green shells, rebon shrimp (small shrimp) and various types of fish. Once sorted then taken to the market for sale at retailers (basket). Regarding the price depends on the season can sometimes sell for high (expensive) or cheap price. Regardless of the proceeds of sale / income earned is used to finance the family life of fishermen.

The condition of the fisherman's house is varied, some have houses with permanent buildings but not yet ( $\pm 60 \%$ ), some also have semi-permanent houses, wall under walls and upper walls of planks, plaster floors, and very simple houses (woven bamboo walls, And boards, floor boards, grounding hardened with pile of shells.

The educational background of parents in general is elementary and junior high school, but there is also a high school education / vocational school. However, the number is only two people, namely in one family, husband educated high school, another family elementary school wife, wife educated SMK, husband of junior high school. Because the wife educated SMK hence can be used to work at garment company. Because the wife works then can increase family income and improve family welfare.

This is in line with the opinion of Kusnadi, (2009) Fishermen society, like other communities, also faces a number of complex social, economic and political problems. The problems are as follows: 1. poverty; Social inequality, and economic pressures that come at all times; 2. limited access to capital, technology, and markets, thus affecting business dynamics; 3. weakness of existing socio-economic institutional function; 4. low quality of human resources (HR) as a result of limited access to education, health, and public services; 5. degradation of environmental resources, both in coastal areas, sea, and small islands and 6. not yet strong maritime-oriented 
policy as the main pillar of national development.

\section{Family Education Patterns of Urban Poor Fishermen In Planting Values of Early Childhood Character}

The fishermen's family education patterns include teaching good manners, providing good examples, giving love, teaching virtues, applying family caring and giving attention to young children. How to teach courtesy in early childhood by getting children to ask permission when leaving for school, borrowing things from friends, playing with friends, getting in touch and greeting friends and neighbors when meeting, getting used to say sorry, excuse, help and Thank you, give examples of good eating, and teach the etiquette in communicating with the elderly, teachers, and friends. Giving exemplary by parents in addition to teaching about manners also provides a concrete example on an ongoing basis.

Every parent would love his children, as well as the fishing family. Based on the results of interviews with the parents found that how to give love to their children vary among others in a way gently and firmly done in accordance with the conditions. For example when the child according to the parents then used a gentle way, but if the child is stubborn then the parents act decisively. Caressing a child, using dear calls, giving love kisses, is still done in early childhood. But if the child is already big the habits are not done anymore because the child feel ashamed to be kissed by his parents and parents feel awkward to kiss his big son. Meeting the needs of life is seen as a form of affection as well as parental responsibility to the child. Although family income is only sufficient for primary needs (meals), parents try to meet other important needs (school) by indebted to family or neighbors.

Virtue needs to be implanted in the child as early as possible because as a social human being must need others and help each other in his life. Parents try to instill virtue on their children in terms of caring for the sesame in the form of giving difficulties, eg dividing supplies for friends who do not bring food, lend the stationery if his friend forgot to bring it, and various kinds of virtues that can be done by early childhood. If the child has been accustomed to perform virtue early on, it will grow and develop a sense of empathy that is, feel the feelings of others.
For example, feel sad if parents and friends feel sad, join happy / happy if others happy / happy.

In line with the results of the Mizal study (2014: 157) describes that the family has a very strategic position as the first emotional investment place of children in the early days of development, the privileged position of the parents can also be a weak point for the character formation of children. Therefore, there is no correlation between the ability to give birth to children and the ability of parents themselves to become educators. To be a parent is only a necessary biological prerequisite, whereas to be an educator requires experience, expertise, and understanding of pedagogy. Thus, the vision of education and the physiological beliefs, and the personal experience of parents about the education of the child that determines whether or not a parent becomes a value educator for his or her children.

\section{The Role of Parents in the Cultivation of Character Values in the Poor Urban Fisherman Family}

Self-esteem is one of the indispensable abilities of children in common life as members of society. By having the confidence of the child easily adapt wherever located. In addition, it can also avoid the unpleasant treatment done by others, such as friends or adults who like membully. It is therefore important for parents to develop selfconfidence in their young children. Efforts that parents make in developing their child's confidence is by giving children the opportunity to follow the race, not waiting for their children at school, participate in the commemoration of the big day both in school and in the village.

As religious followers children should be accustomed to praying at all times, for example before doing or doing something in order to finish properly. In accordance with the results of interviews with parents who stated that children are always getting used to pray before running something, eg eating, studying, and leaving school. In addition to getting used to the child is always grateful for all the grace of God. If the child is accustomed to being grateful then God will increase / increase His grace, as the parents tell at the time of the interview.

Independence is one of the abilities children must have in order to adapt to the social environment. This ability, is one of the good character values that must be developed 
first by parents. Children should be accustomed to take care of themselves in order to increase the confidence in social interaction. Parents' efforts to train children's self-reliance are to familiarize children in their own clothes, to go to school themselves, to feed themselves (self-feeding), to bathe themselves, and to do activities that children can do according to their abilities.

Implanting and training discipline in early childhood is a problem that requires effort is not easy, because it requires patience and wisdom and special attention. But it is not easy to train and instill discipline in children if not accompanied by examples and parental example. As the subject said during the interview, that as a parent always taught and trained the discipline in his / her child by getting used to sleeping at the set time and agreed to wake up early, but sometimes at the appointed time the child was not sleepy And unable to sleep in time, so waking up late. Other subjects train and familiarize the discipline by getting children to do things according to the time they have set, eg learning, going to school, studying, napping, and so on.

A sense of responsibility needs to be instilled and familiarized in children from an early age. Children feel happy and proud if given the responsibility and can perform well. Responsible children can act appropriately in their capacity and without the help of others. The sense of responsibility in the child appears in the way they perform their routine tasks, for example, have been used to put toys, shoes, and other items in place. The cultivation of sense of responsibility in early childhood is not sufficient to just be told, but needs exemplary and concrete examples from their parents. This is reinforced by the opinion of some subjects who have tried to instill a sense of responsibility in children who are still in the early years requires patience and affection. In addition, parents should give real examples, such as putting things in place, the mother responsible for the availability of food for the family and other domestic duties that are the responsibility of the mother. Father is responsible to work to earn a living to meet the needs of his family life.

Cooperation, as social beings, children need to be trained to work with others, parents, friends, and others, in accomplishing tasks that require the help of others, because not all tasks must be solved on their own. The cultivation of behaviors to work with others needs to be given to children at an early age, because the ability to cooperate is needed in the life of society. Forms of cooperation in early childhood in the family can be through the habit of doing work together for example when the mother cooks, children are assigned to do light work, take cooking utensils, cut vegetables and others that do not harm children. Cooperation exercise is also carried out by the research subjects by cleaning the house together on a holiday that involves all family members namely father, mother, and child. At the time of the mother ironing the clothes, the child is assigned to put the clothes that have been neatly into the clothes cupboard.

All of these character values are in line with Mullin's (2005) opinion which confirms that good parents do more than give love and meet the needs of their children. Parents should plan how they will shape the character of their children.

Educational Needs of Urban Poor Fishermen in Planting the Values of Early Childhood Character

Increasing the ability of parents to educate and instill character values in early childhood in poor urban fishing families, parents need to learn from various sources. Parents often watch television-related shows and engage in the values of early childhood characters. In addition, to improve the knowledge and skills to educate young children, parents at least once a month follow the activities held at the PKK meeting (the development of family welfare that brings in sources from BKB (Bina Keluarga balita), puskesmas, and other institutions related to Early child development.

Meetings held to improve the knowledge, abilities and skills of parents are deemed necessary to be complemented by the publication of simple guidebooks that are easy to understand and apply in educating and instilling the values of early childhood character. Cultivation of the child's character values from an early age is expected and prevent the child's behavior towards destructive later in the future. This is in line with the opinion of Yuwono (2010) that character behaviors can be realized through values practiced at home (family).

\section{CONCLUSION}

1. The socio-economic condition of the fishing family is uncertain, the income of the fishermen is unpredictable depending on the natural conditions. The background of parent 
education is relatively low (elementary, junior high school), with only two senior high school / vocational education.

2. Family fishermen in the socio-economic conditions are still limited to implement a family education in accordance with ability. With full awareness, parents include early childhood in kindergarten, Paud, and Pospaud. 3. The inculcation of character values in early childhood is carried out in a simple way through refraction, examples and exemplary from parents, naturally and hereditary.

4. Family fishermen need guidebooks to educate and inculcate the values of character to early childhood, in order to implement properly and not mistakenly.

\section{REFERENCES}

[1] Agus Sjafari, 2014. Kemiskinan dan Pemberdayaan Masyarakat. Yogyakarta:Graha Ilmu.

[2] BPS Provinsi Jawa Tengah. 2015. Jawa Tengah dalam Angka. Semarang

[3] Dewantara, Ki Hajar. 1977. Pendidikan. Yogyakarta: Majelis Hukum Persatuan Taman Siswa.

[4] Emmy Budiartati. 2011. Pengembangan Kreativitas Seni pada Anak Usia Dini di Masyarakat Nelayan Tambak Lorok, Kota Semarang. Laporan Penelitian. Tidak dipublikasikan.

[5] Gall, M.D., Gall, J.P., \& Borg, W.R. 20 07. Educational research:An Introdu ction. (Eighthedition). United State s of America: Pearson Education.

[6] Hasby Wahy, 2012. Keluarga sebagai Basis Pertama dan Utama.Jurnal Didaktika: MediaIlmiah Pendidikan dan Pengajarannya. Vol.XII, No 2, Februari 2012. ISSN 1411-612.

[7] Hurlock, Elizabeth B. 1978. Perkembangan Anak Jilid 2. (terjemahan). Jakarta: Penerbit Erlangga.

[8] Izzaty, Rika Eka.(2008). Peran Aktivitas Pengasuhan Pada Pengasuhan Perilaku Anak Sejak Usia Dini (Kajian Psikologis Berdasarkan Teori Sistem Ekologi). Tinjauan Berbagai Aspek Character Building. Yogyakarta: Penerbit Tiara Wacana

[9] Jamaris, Martini. 2004. Perkembangan dan Pengembangan Anak Usia
Taman Kanak-Kanak, Pedoman bagi Orangtua dan Guru. Jakarta: Program Pendidikan Anak Usia Dini, PPs Universitas negeri Jakarta.

[10] Koesoema A, Doni. 2007. Pendidikan Karakter: Strategi Mendidik Anak di Zaman Global. Jakarta: Grasindo.

[11] Lickona,T.(1992). Educating for Character, How Our Schools Can Teach Respect and Responsibility. New York: Bantam Book.

[12] Lickona, 2001. Character Education. Whasington: Connecticut Avenue.

[13] Mizal, Bazidin.2014. Pendidikan dalam Keluarga.Jurnal Peuradeun:kajian Iliah, sosial politik, sosial Budaya. Volume 2 , Nomor 3 , September 2014. ISBN 2338-8617. Hal 155-178.

[14] Moleong, Lexy. 2007.Metodologi Penelitian Kualitatif. Bandung: Rosda.

[15] Muhammad Idrus. Pendidikan Karakter pada Keluarga Jawa. Jurnal Pendidikan Karakter, Tahun II, Nomor 2, Juni 2012. Hal 118130.

[16] Mullin, Andrew. (2005). Parenting for Character. Sydney: Finch Publishing.

[17] Musfiroh,Tadkiroatun. (2008). Pengembangan Karakter Anak Melalui Pendidikan Karakter. Tinjauan Berbagai Aspek Character Buiding. Yogyakarta : Penerbit Tiara Wacana

[18] Sudarsono, Juwono.2010. Pendidikan Karakter Bangsa Dimulai di Rumah. Jakarta

[19] Sumarta, I Ketut. 2000. Pendidikan yang Memekarkan Rasa (dalam Membuka Masa Depan Anak-Anak Kita). Yogyakarta: Penerbit Kanisius.

[20] Yulaelawati, Ella. (2010). Mengapa perlu Pendidikan Karakter? Jurnal AKRAB (Aksara agar Berdaya) Pendidikan Karakter. Volume I. Edisi 3, September 2010, hal 03 -06.

[21] http://print.kompas.com/baca/2015/0 7/29/Memutus-Mata-RantaiKekerasan-terhadap-Anak. diunggah 29 Mei 2016. 